\title{
ARTICLE
}

\section{Enhancing Resilience and Justice in Climate Adaptation Laws}

\author{
Joseph Wenta, Jan McDonald** and Jeffrey S. McGee***
}

First published online 4 December 2018

\begin{abstract}
Resilience thinking - an approach for understanding and managing change - is increasingly central to climate change adaptation law and policy. Yet the influence of adaptation law and policy on the distribution of climate impacts is often overlooked in studies of socioecological resilience to climate change. This article demonstrates how environmental justice scholarship helps to address this gap in the literature relating to adaptation law and resilience. Drawing on existing literature, the article identifies four principles to promote resilience and justice through climate adaptation laws. Climate adaptation laws must (i) prepare for, and respond to, change; (ii) address the distributive effects of climate change and adaptation; (iii) promote participation in adaptation processes; and (iv) cross sectors and scales. Each criterion can be implemented in part through existing legal processes, but might also be further supported by incremental law reform. Developing both resilience and justice dimensions will enhance the effectiveness of adaptation laws in addressing climate impacts.
\end{abstract}

Keywords: Climate change, Impacts, Adaptation, Resilience thinking, Socio-ecological resilience, Environmental justice

\section{INTRODUCTION}

The biophysical and associated environmental, social, and economic impacts of climate change are well documented. ${ }^{1}$ There is already a vast literature on how

* Faculty of Law, University of Tasmania; Centre for Marine Socioecology, Hobart, Tasmania (Australia). Joseph's PhD candidature is supported by an Australian Government Research Training Program (RTP) Scholarship.

Email: Joseph.Wenta@utas.edu.au.

* Faculty of Law, University of Tasmania; Centre for Marine Socioecology, Hobart, Tasmania (Australia).

Email: Jan.McDonald@utas.edu.au.

$\because *$ Faculty of Law, University of Tasmania; Institute for Marine and Antarctic Studies and Centre for Marine Socioecology, Hobart, Tasmania (Australia).

Email: Jeffrey.McGee@utas.edu.au.

The authors acknowledge Dr Aysha Fleming's thoughtful feedback on earlier versions of this manuscript, and thank TEL's anonymous reviewers for their helpful comments.

1 T.F. Stocker et al., 'Summary for Policymakers', in T.F. Stocker et al. (eds), Climate Change 2013: The Physical Science Basis. Contribution of Working Group I to the Fifth Assessment Report of the Intergovernmental Panel on Climate Change (Cambridge University Press, 2013), pp. 3-29. 
societies should adapt to these impacts, including through technological, behavioural, and management reforms. ${ }^{2}$ The concept of socio-ecological resilience and related principles of 'resilience thinking' underpin much of this adaptation research and associated policy development. ${ }^{3}$ At the same time, distributive justice concerns are highlighted in impacts and adaptation literature, which emphasizes the inequities of climate change ${ }^{4}$ and recognizes that climate impacts fall disproportionately on those with the lowest adaptive capacity. ${ }^{5}$ Growing scholarly interest in the links between resilience thinking and justice is thus unsurprising, and necessary. ${ }^{6}$

It is increasingly recognized that law plays a critical role in adapting to climate change by helping to reduce exposure to climate hazards; increasing the adaptive capacity of individuals, households and communities; and creating incentives for climate-adaptive behaviour. ${ }^{7}$ This work shows not only that law is a key mechanism for implementing policies to promote socio-ecological resilience in the face of climate change, but that it can also inhibit societal responses to climate impacts. ${ }^{8}$ A key challenge is how laws can provide continued stability while also promoting responsiveness to climate-induced environmental change through procedural and substantive law reform. ${ }^{9}$

Although adaptation laws recognize the need to address change over time, they typically overlook the differential impacts of climate change across space and social conditions. ${ }^{10}$ Applications of socio-ecological resilience principles to law have largely

2 I.R. Noble et al., 'Adaptation Needs and Options', in C.B. Field et al. (eds), Climate Change 2014: Impacts, Adaptation, and Vulnerability, Part A: Global and Sectoral Aspects. Contribution of Working Group II to the Fifth Assessment Report of the Intergovernmental Panel on Climate Change (Cambridge University Press, 2014), pp. 833-68, at 845 (Table 14-1).

3 E.g., Australian Government, National Climate Resilience and Adaptation Strategy (Commonwealth of Australia, 2015), available at: http://www.environment.gov.au/system/files/resources/3b44e21e-2a784809-87c7-a1386e350c29/files/national-climate-resilience-and-adaptation-strategy.pdf.

4 J. Paavola \& W.N. Adger, 'Fair Adaptation to Climate Change' (2006) 56(4) Ecological Economics, pp. 594-609, at 596-7.

5 K. Dow, R.E. Kasperson \& M. Bohn, 'Exploring the Social Justice Implications of Adaptation and Vulnerability', in W.N. Adger et al. (eds), Fairness in Adaptation to Climate Change (The MIT Press, 2006), pp. 79-96, at 82.

6 B.S. Caniglia. M. Vallée \& B. Frank (eds), Resilience, Environmental Justice and the City (Routledge, 2017); B.M. Hutter (ed.), Risk, Resilience, Inequality and Environmental Law (Edward Elgar, 2017).

7 L. Berrang-Ford et al., 'What Drives National Adaptation? A Global Assessment' (2014) 124 Climatic Change, pp. 441-50, at 448 .

8 O.O. Green et al., 'Barriers and Bridges to the Integration of Social-Ecological Resilience and Law' (2015) 13(6) Frontiers in Ecology and the Environment, pp. 332-7.

9 R.K. Craig et al., 'Balancing Stability and Flexibility in Adaptive Governance: An Analysis of Tools Available in US Environmental Law' (2017) 22(2) Ecology and Society online articles, article 3, pp. 6-10, available at: https://www.ecologyandsociety.org/vol22/iss2/art3/ES-2016-8983.pdf. On the challenges of incorporating flexibility into environmental laws, see E. Biber \& J. Eagle, 'When Does Legal Flexibility Work in Environmental Law?' (2015) 42(4) Ecology Law Quarterly, pp. 787-840, at 791-800; and International Risk Governance Council, Transatlantic Patterns of Risk Regulation: Implications for International Trade and Cooperation (EPFL International Risk Governance Center, 2017), pp. 60-1.

10 J. McDonald, 'The Role of Law in Adapting to Climate Change' (2011) 2(2) Wiley Interdisciplinary Reviews: Climate Change, pp 283-95, at 288. 
neglected distributive dimensions. ${ }^{11}$ This is surprising, considering the importance of law in shaping the social, cultural, and economic circumstances that influence individuals' experiences of climate change and their adaptive capacity. ${ }^{12}$ Responding to the inequitable distribution of climate change impacts and adaptive capacities is therefore an important new focus for adaptation law scholarship and practice. ${ }^{13}$ This article addresses the gap in adaptation scholarship by drawing together the concepts of resilience thinking, environmental justice, and climate adaptation to propose a set of principles for the design and implementation of resilient and just climate adaptation law.

The article proceeds in four parts. Following this introduction, Part 2 introduces the concept of resilience thinking, identifies its key features, and examines its application to climate adaptation law. Part 3 undertakes a similar analysis in respect of the concept of environmental justice. Part 4 analyzes the intersections of resilience thinking and environmental justice, first by reviewing the available literature, then by elaborating four principles that we consider essential for promoting resilience and justice through climate adaptation laws. These principles are that legal arrangements must (i) prepare for, and respond to, change; (ii) address the distributive effects of climate change and adaptation; (iii) promote participation in adaptation processes; and (iv) cross sectors and scales. Each principle is examined in detail, and is accompanied by examples outlining how it might be implemented. Most examples are from domestic legal systems, where most adaptation law and policy is developed and implemented. ${ }^{14}$ Part 5 concludes that the proposed principles should be the focus of future reform efforts in order for law to fulfil its role in facilitating fair and resilient adaptation to climate impacts.

\section{RESILIENCE THINKING, CLIMATE CHANGE}

\section{ADAPTATION AND LAW}

'Resilience thinking' is an approach to understanding and better managing the world in response to change, based on the concept of socio-ecological resilience. $^{15}$ Socio-ecological resilience refers to the capability of a system to

11 Major contributions have focused largely on procedural dimensions of justice: e.g., B.A. Cosens et al., 'The Role of Law in Adaptive Governance' (2017) 22(1) Ecology and Society online articles, article 30, p. 2, available at: https://www.ecologyandsociety.org/vol22/iss1/art30/ES-2016-8731.pdf. On the distributive consequences of law and governance, see J. Paavola, 'Protected Areas Governance and Justice: Theory and the European Union's Habitats Directive' (2004) 1(1) Environmental Sciences, pp. 59-77, at 67.

12 H. Doremus, 'Constitutive Law and Environmental Policy' (2003) 22 Stanford Environmental Law Journal, pp. 295-378.

13 J.B. Ruhl, 'Climate Change Adaptation and the Structural Transformation of Environmental Law' (2010) 40(2) Environmental Law, pp. 363-435, at 406-9 and 426-31.

14 McDonald, n. 10 above, p. 288. Note, however, that adaptation is not limited to domestic legal systems; some examples therefore focus on the international or global scale. The principles are equally capable of application - perhaps with differing emphases - to both domestic and international climate law and governance.

15 B. Walker \& D. Salt, Resilience Thinking: Sustaining Ecosystems and People in a Changing World (Island Press, 2006), pp. 9-10. 
maintain important features by self-organizing and adapting to unexpected disturbances and change. ${ }^{16}$ The capacity to learn from previous experience and to take pre-emptive measures to address the prospect of change, rather than simply 'bouncing back' from impacts, distinguishes socio-ecological from other approaches to resilience. ${ }^{17}$ While resilience thinking is used across a broad range of contexts that extend beyond climate and environmental change, it now dominates scholarly and practical approaches to climate change adaptation. ${ }^{18}$ Resilience thinking has four core concepts that are particularly important for adaptation laws and legal systems: (i) socio-ecological systems; (ii) thresholds and regime shifts; (iii) the adaptive cycle; and (iv) cross-scale interactions and panarchy.

The concept of socio-ecological systems comprehends the Earth system as consisting of linked biophysical and socio-political arrangements that are inextricably connected. ${ }^{19}$ Socio-ecological resilience recognizes that 'the biophysical system constrains and shapes people and their communities, just as people shape the biophysical system', ${ }^{20}$ a view which can be contrasted with purely ecological and social understandings of resilience that tend to conceive of biophysical and socio-political systems separately. ${ }^{21}$ Acknowledging this interconnectedness in socio-ecological systems encourages attention to a wider range of feedbacks, which may in turn shape environmental and resource management strategies.

16 B. Walker et al., 'Resilience, Adaptability and Transformability in Social-Ecological Systems' (2004) 9(2) Ecology and Society online articles, article 5, p. 3, available at: https://www.ecologyandsociety. org/vol9/iss2/art5/print.pdf.

17 C. Folke, 'Resilience: The Emergence of a Perspective for Social-Ecological Systems Analyses' (2006) 16(3) Global Environmental Change, pp. 253-67, at 259. The socio-ecological approach to resilience builds on the scholarship of C.S. Holling, who challenged the assumption that ecosystems respond to disturbances by rebounding to a static equilibrium (i.e. 'engineering resilience'). He instead demonstrated that ecosystems persist by responding dynamically to change, including by shifting to new system states in order to maintain key features: 'ecological resilience', then, referred to 'the persistence of systems .... and their ability to absorb change and disturbance and still maintain the same relationships between populations or state variables': C.S. Holling, 'Resilience and Stability of Ecological Systems' (1973) 4 Annual Review of Ecology and Systematics, pp. 1-23, at 14. See also L.H. Gunderson \& C.R. Allen, 'Why Resilience? Why Now?', in L.H. Gunderson, C.R. Allen \& C.S. Holling (eds), Foundations of Ecological Resilience (Island Press, 2010), pp. xiii-xxv, at xiii, $\mathrm{xiv}-\mathrm{xv}$. In the remainder of this article, we use 'resilience' to refer to socio-ecological resilience.

18 C. Folke, 'Resilience (Republished)' (2016) 21(4) Ecology and Society online articles, article 44, p. 1, available at: https://www.ecologyandsociety.org/vol21/iss4/art44/ES-2016-9088.pdf; S. Deppisch \& S. Hasibovic, 'Social-Ecological Resilience Thinking as a Bridging Concept in Transdisciplinary Research on Climate-Change Adaptation' (2013) 67(1) Natural Hazards, pp. 117-27, at 120-2; H. Füngfeld \& D. McEvoy, 'Resilience as a Useful Concept for Climate Change Adaptation' (2012) 13(2) Planning Theory and Practice, pp. 324-8.

19 E. Ostrom, 'A General Framework for Analyzing Sustainability of Social-Ecological Systems' (2009) 325(5939) Science, pp. 419-22, at 419.

20 Walker \& Salt, n. 15 above, pp. 32, 34. B. Walker et al., 'A Handful of Heuristics and Some Propositions for Understanding Resilience in Social-Ecological Systems' (2006) 11 Ecology and Society online articles, article 13, pp. 3, 6, available at: https://www.ecologyandsociety.org/vol11/iss1/art13/ ES-2005-1530.pdf.

21 Ecological approaches to resilience are discussed at $n .17$ above. The application of ecological resilience concepts to social systems has been referred to as social resilience: W.N. Adger, 'Social and Ecological Resilience: Are They Related?' (2000) 24(3) Progress in Human Geography, pp. 347-64, at 361. 
The concepts of thresholds and regime shifts recognize that socio-ecological systems are constantly evolving, ${ }^{22}$ but seldom develop in an incremental, linear manner. ${ }^{23}$ Thresholds are the tipping points or levels of key variables ${ }^{24}$ that influence a system state. ${ }^{25}$ Systems are generally less resilient as they approach thresholds, ${ }^{26}$ but may exercise adaptability or adaptive capacity to maintain existing system functions. ${ }^{27}$ When a key variable crosses a threshold, the system may shift to another state. ${ }^{28}$ Systems transform by reconfiguring key variables and feedbacks to establish a substantially different regime. ${ }^{29}$ While some scholars suggest that law has little to contribute to transformations, ${ }^{30}$ others take the view that law and governance can initiate substantial changes in socio-ecological systems. ${ }^{31}$ These two properties of adaptability and transformability thus identify the potential for systems either to change to avoid shifts to less desirable regimes, or to convert to more desirable system states.

The concepts of thresholds and regime shifts have important implications for legal interventions that aim to facilitate climate change adaptation. Laws intended to maintain a particular system state might try to enhance adaptive capacity. ${ }^{32}$ For example, fisheries managers might use decision rules in harvest strategies to automatically adjust catch limits when new data indicates that stock levels have declined. ${ }^{33}$ Laws may be used also to trigger a regime shift away from an undesirable state - that is, enable transformation to a more desirable system state. ${ }^{34}$ For example,

22 R. Biggs, M. Schlüter \& M.L. Schoon, 'An Introduction to the Resilience Approach and Principles to Sustain Ecosystem Services in Social-Ecological Systems’, in R. Biggs, M. Schlüter \& M.L. Schoon (eds), Principles for Building Resilience: Sustaining Ecosystem Services in Social-Ecological Systems (Cambridge University Press, 2015), pp. 1-31, at 6, 9.

23 C. Rammel, S. Stagl \& H. Wilfing, 'Managing Complex Adaptive Systems: A Co-evolutionary Perspective on Natural Resource Management' (2007) 63(1) Ecological Economics, pp. 9-21, at 10.

24 Although systems may comprise many variables, certain 'key' variables drive those systems: U. Pisano, 'Resilience and Sustainable Development: Theory of Resilience, Systems Thinking and Adaptive Governance', European Sustainable Development Network, ESDN Quarterly Report No. 26, Sept. 2012, p. 13, available at: https://www.sd-network.eu/quarterly\%20reports/report\%20files/pdf/2012September-Resilience_and_Sustainable_Development.pdf.

25 Walker \& Salt, n. 15 above, p. 53.

26 Ibid., p. 55.

27 Walker et al., n. 16 above, p. 3.

28 Walker \& Salt, n. 15 above, pp. 55, 59.

29 Walker et al., n. 16 above, p. 3.

30 C.S. Holling, 'Response to "Panarchy and the Law"' (2012) 17(4) Ecology and Society online articles, article 37, p, 1, available at: https://www.ecologyandsociety.org/vol17/iss4/art37/ES-2012-5402.pdf.

31 B.C. Chaffin, R.K. Craig \& H. Gosnell, 'Resilience, Adaptation, and Transformation in the Klamath River Basin Social-Ecological System’ (2014) 51(1) Idaho Law Review, pp. 157-93, at 190.

32 V.B. Flatt, 'Adapting Laws for a Changing World: A Systemic Approach to Climate Change Adaptation’ (2012) 64(1) Florida Law Review, pp. 269-93, at 290-1.

33 E.g., Australian Government, Department of Agriculture, Fisheries and Forestry, Commonwealth Fisheries Harvest Strategy: Policy and Guidelines, Sept. 2007; see also J. McDonald \& M. Styles, 'Legal Strategies for Adaptive Management under Climate Change' (2014) 26(1) Journal of Environmental Law, pp. 25-53, at 46.

34 B.C. Chaffin et al., 'Transformative Environmental Governance' (2016) 41 Annual Review of Environment and Resources, pp. 399-423, at 410-1. 
land-use planning laws could restrict development in bushfire-prone areas to reduce overall exposure to such risks.

The third key concept in resilience thinking is the idea of the 'adaptive cycle', which outlines four key phases in system dynamics: ${ }^{35}$

- 'rapid growth', in which systems have plentiful resources to respond dynamically to unexpected events; ${ }^{36}$

- 'conservation', in which systems become more efficient but less adaptable to unexpected disturbances as they approach thresholds;

- 'release', in which established functions are destroyed following the crossing of a threshold ${ }^{37}$ and

- 'reorganization', in which new structures and thresholds are then established. ${ }^{38}$

The 'release' and 'reorganization' phases provide the greatest opportunity for human intervention, including through law, to shape thresholds and feedbacks in the socioecological system. ${ }^{39}$ The adaptive cycle also highlights the importance of monitoring feedbacks and variables that might signal the approach of thresholds and thus explain changing system dynamics.

The final concept critical to an understanding of how resilience thinking interacts with law is the idea of multi-scale interactions. The term 'panarchy' refers to the hierarchy of interrelated socio-ecological systems that collectively comprise the larger and more complex system. ${ }^{40}$ Each of these systems experiences the adaptive cycle on different spatial and temporal scales; each scale is both independent (with its own structures and functions) and influenced by processes occurring on other scales. Lower levels can 'trigger a crisis' or help to slow progression towards a release phase on a higher scale, ${ }^{41}$ while higher scales of a panarchy provide 'memory' which may shape dynamics on lower scales. ${ }^{42}$

The concept of panarchy has implications for governance arrangements because it highlights the importance of focusing on multiple sectors and scales. ${ }^{43}$ For example, the management of protected wetlands to promote resilience under climate change involves a complex mix of international laws,

35 Walker \& Salt, n. 15 above, p. 75.

36 Walker et al., n. 16 above, p. 2.

37 C.R. Allen et al., 'Panarchy: Theory and Application' (2014) 17(4) Ecosystems, pp. 578-89, at 579; S. Carpenter et al., 'From Metaphor to Measurement: Resilience of What to What?' (2001) 4(8) Ecosystems, pp. 765-81, at 766.

38 Walker et al., n. 16 above, p. 2.

39 Walker \& Salt, n. 15 above, p. 75.

40 The term 'panarchy' combines the words 'Pan' (the name of the Greek god of nature, representing unpredictable change) and 'hierarchy' (representing the multi-level character of socio-ecological systems): see C.S. Holling, L. Gunderson \& G.D. Peterson, 'Sustainability and Panarchies', in L.H. Gunderson \& C.S. Holling (eds), Panarchy: Understanding Transformations in Human and Natural Systems (Island Press, 2002), pp. 63-102, at 72-4.

41 Ibid., pp. 75-6.

42 Ibid., p. 76.

43 Walker \& Salt, n. 15 above, p. 90. 
national or subnational legislation, and localized management plans. ${ }^{44}$ These arrangements span a range of sectors, which include coastal management, biodiversity conservation, land-use planning, catchment and water management, and tourism. They involve both governmental and non-governmental actors (community-based environmental groups or tourism industry bodies, for example). Successful management demands the coordination of all these disparate regimes.

Despite its prominence in academic and policy circles, social scientists have questioned the merit of resilience thinking, especially the characterization of human societies as 'systems'. 45 Concerns commonly raised include (i) the capacity of methodologies in resilience thinking research to comprehend the social domain and accommodate 'different ways of knowing'; ${ }^{46}$ (ii) the tendency of resilience thinking to underplay the influence of human agency and power dynamics within socioecological systems; ${ }^{47}$ and (iii) the susceptibility of resilience concepts to politicization. ${ }^{48}$ Resilience thinking has also been criticized for failing to offer normative guidance for management of socio-ecological systems - that is, for interpreting how a system operates in practice, without considering whether the resilient state is socially desirable. ${ }^{49}$ It is beyond the scope of this article to address these concerns in detail, but they highlight the need to address the fairness and equity implications of resilience thinking. By integrating environmental justice and resilience thinking (in Part 4), this article thus helps to develop connections between the social and natural sciences. 50

44 L.H. Gunderson et al., 'Escaping a Rigidity Trap: Governance and Adaptive Capacity to Climate Change in the Everglades Social Ecological System' (2014) 51(1) Idaho Law Review, pp. 127-56; see also A. Garmestani \& M.H. Benson, 'A Framework for Resilience-based Governance of SocialEcological Systems' (2013) 18(1) Ecology and Society online articles, article 9, pp. 6-7, available at: https://www.ecologyandsociety.org/vol18/iss1/art9/ES-2012-5180.pdf.

45 D.J. Davidson, 'The Applicability of the Concept of Resilience to Social Systems: Some Sources of Optimism and Nagging Doubts' (2010) 23(12) Society and Natural Resources, pp. 1135-49, at 1143. W.N. Adger et al., 'Are There Social Limits to Adaptation to Climate Change?' (2008) 93(3-4) Climatic Change, pp. 335-54.

46 T. Stojanovic et al., 'The "Social" Aspect of Socio-Ecological Systems: A Critique of Analytical Frameworks and Findings from a Multisite Study of Coastal Sustainability' (2016) 21(3) Ecology and Society online article, article 15, pp. 3-4, 10, available at: https:/www.ecologyandsociety.org/vol21/ iss3/art15/ES-2016-8633.pdf.

47 Davidson, n. 45 above, pp. 1142-4; R. Cretney, 'Resilience for Whom? Emerging Critical Geographies of Socio-Ecological Resilience' (2014) 8/9 Geography Compass, pp. 627-40, at 632, 634; M. Cote \& A.J. Nightingale, 'Resilience Thinking Meets Social Theory: Situating Social Change in Socio-Ecological Systems (SES) Research' (2012) 36(4) Progress in Human Geography, pp. 475-89, at 479.

48 J. Joseph, 'Resilience as Embedded Neoliberalism: A Governmentality Approach' (2013) 1(1) Resilience: International Policies, Practices and Discourses, pp. 38-52, at 39; see also J. Walker \& M. Cooper, 'Genealogies of Resilience: From Systems Ecology to the Political Economy of Crisis Adaptation’ (2011) 42(2) Security Dialogue, pp. 143-60.

49 D. MacKinnon \& K.D. Derickson, 'From Resilience to Resourcefulness: A Critique of Resilience Policy and Activism' (2012) 37(2) Progress in Human Geography, pp. 253-70, at 258-9.

50 J.L. Davidson et al., 'Interrogating Resilience: Toward a Typology to Improve its Operationalization' (2016) 21(2) Ecology and Society online articles, article 27, p. 3, available at: https://www.ecolo gyandsociety.org/vol21/iss2/art27/ES-2016-8450.pdf. 


\subsection{Resilience Thinking and Climate Adaptation Law}

Given the centrality of resilience thinking in climate adaptation policy, there has been growing interest in its application to climate adaptation law. ${ }^{51}$ The 'law and resilience' literature is premised on the ideas that enhancing resilience ${ }^{52}$ and increasing adaptability is advantageous and that legal and governance arrangements can play a role in that process. The literature draws on examples and case studies from the United States (US), ${ }^{53}$ and typically uses resilience thinking principles to analyze existing laws and governance arrangements. ${ }^{54}$ Scholars have characterized legal systems as nested components of socio-ecological systems; ${ }^{55}$ explored the potential relevance of thresholds and the adaptive cycle for law and governance; ${ }^{56}$ identified opportunities for legal systems and governance arrangements to facilitate adaptability and transformability; ${ }^{57}$ and recognized that socio-ecological systems often cross jurisdictional scales. ${ }^{58}$ Studies that explore potential reforms have

51 There are two discernible strands in the literature exploring the relationship between law and resilience: the 'resilience of legal systems' literature, which applies the resilience approach to legal systems themselves (see, e.g., J.B. Ruhl, 'General Design Principles for Resilience and Adaptive Capacity in Legal Systems - With Applications to Climate Change Adaptation' (2011) 89(5) North Carolina Law Review, pp. 1373-403, at 1379-85), and a 'law for resilience' literature, which uses the principles of resilience thinking to assess and enhance the influence of law in promoting resilience. This article examines the latter aspect of the existing literature; a similar approach is adopted in S. Niall \& A. Kallies, 'Electricity Systems between Climate Mitigation and Climate Adaptation Pressures: Can Legal Frameworks for "Resilience" Provide Answers?" (2017) 34(6) Environmental and Planning Law Journal, pp. 488-502, at 492.

52 Socio-ecological resilience is the most prominent approach to resilience identified in this literature. For a notable exception, see M.J. Angelo, 'Stumbling Toward Success: A Story of Adaptive Law and Ecological Resilience' (2008) 87(4) Nebraska Law Review, pp. 950-1007, at 959-65.

53 Many of the key sources identified in this article stem from a core group of US legal and interdisciplinary scholars who have developed major research projects investigating the relationship of resilience thinking and law: see C.A. Arnold et al., 'Cross-Interdisciplinary Insights into Adaptive Governance and Resilience' (2017) 22(4) Ecology and Society online articles, article 14, p. 13, available at: https://www.ecologyandsociety.org/vol22/iss4/art14/ES-2017-9734.pdf. European and Australian examples are less prominent: see, e.g., A.M. Keessen \& H.F.M.W. van Rijswick, 'Adaptation to Climate Change in European Water Law and Policy' (2012) 8(3) Utrecht Law Review, pp. 38-50; and J. McDonald, P.C. McCormack \& A. Foerster, 'Promoting Resilience to Climate Change in Australian Conservation Law: The Case of Biodiversity Offsets' (2016) 39(4) University of New South Wales Law Journal, pp. 1612-51; and Niall \& Kallies, n. 51 above.

54 E.g., Ruhl, n. 13 above; R.K. Craig, "“Stationarity is Dead" - Long Live Transformation: Five Principles for Climate Change Adaptation Law' (2010) 34(1) Harvard Environmental Law Review, pp. 9-73; A.E. Camacho \& T.D. Beard, 'Maintaining Resilience in the Face of Climate Change', in A.S. Garmestani \& C.R. Allen (eds), Social-Ecological Resilience and Law (Columbia University Press, 2014), pp. 235-64; B. Cosens et al., 'Identifying Legal, Ecological and Governance Obstacles, and Opportunities for Adapting to Climate Change' (2014) 6(4) Sustainability, pp. 2338-56.

55 E.g., S. Zellmer \& L. Gunderson, 'Why Resilience May Not Always Be a Good Thing: Lessons in Ecosystem Restoration from Glen Canyon and the Everglades' (2008) 87(4) Nebraska Law Review, pp. 893-949, at 898.

56 E.g., M.H. Benson, 'Reconceptualizing Environmental Challenges: Is Resilience the New Narrative?' (2015) 21(1) Journal of Environmental and Sustainability Law, pp. 99-126, at 116-7; H.E. Birge et al., 'Social-Ecological Resilience and Law in the Platte River Basin' (2014) 51(1) Idaho Law Review, pp. 229-56, at 250-2.

57 E.g., C.A. Arnold et al., 'The Social-Ecological Resilience of an Eastern Urban-Suburban Watershed: The Anacostia River Basin' (2014) 51(1) Idaho Law Review, pp. 29-90, at 75-80; Chaffin et al., n. 34 above, pp. 410-1.

58 E.g., A.S. Garmestani, C.R. Allen \& H. Cabezas, 'Panarchy, Adaptive Management and Governance: Policy Options for Building Resilience' (2008) 87(4) Nebraska Law Review, pp. 1036-54, at 1049-51; 
examined how existing legal processes, such as environmental impact assessment, could be improved to better reflect resilience thinking. ${ }^{59}$

Research to date has raised concerns about the capacity of current legal arrangements to operationalize resilience thinking. ${ }^{60}$ Craig, for example, notes that many laws assume that ecological processes are linear ${ }^{61}$ and thus overlook the potential for thresholds and interaction across scales to influence management of socio-ecological systems. ${ }^{62}$ Legal systems tend to disaggregate socio-ecological systems into smaller components based on activity or geography to make them more manageable. As a result, jurisdictional boundaries may not align with the location or scale of environmental or resource management problems (on local, national, or even transnational scales). ${ }^{63}$ This can make the task of integrating management across multiple sectors and scales more complex. ${ }^{64}$ In a similar vein, lawyers and lawmakers often conceive of legal systems as independent of the broader socio-ecological system, ${ }^{65}$ which can limit the capacity of law to contribute to adaptive governance frameworks. ${ }^{66}$ Another common issue in this scholarship is the tension between resilience as 'capacity to respond to change' and the construction of legal systems to provide certainty and stability. ${ }^{67}$ While certainty may be a normatively desirable feature of legal systems, it also reduces the capacity of the law to promote socio-ecological resilience. ${ }^{68}$ Legal structures typically do not support iterative decision-making processes that encourage change. ${ }^{69}$

B. Cosens, 'Resilience and Law as a Theoretical Backdrop for Natural Resource Management: Flood Management in the Columbia River Basin' (2012) 42 Environmental Law, pp. 241-64, at 247, 262; B.A. Cosens \& M.K. Williams, 'Resilience and Water Governance: Adaptive Governance in the Columbia River Basin' (2012) 17(4) Ecology and Society online articles, article 3, p. 10, available at: https://www.ecologyandsociety.org/vol17/iss4/art3/ES-2012-4986.pdf; Birge et al., n. 56 above, pp. 250-2.

59 E.g., A. Bond et al., 'Managing Uncertainty, Ambiguity and Ignorance in Impact Assessment by Embedding Evolutionary Resilience, Participatory Modelling and Adaptive Management' (2015) 151 Journal of Environmental Planning, pp. 97-104, at 99-100.

60 E.g., T.-L. Humby, 'Law and Resilience: Mapping the Literature' (2014) 4(1) Seattle Journal of Environmental Law, pp. 85-130, at 94-5.

61 Craig, n. 54 above, p. 36; R.K. Craig, 'Learning to think about Complex Environmental Systems in Environmental and Natural Resource Law and Legal Scholarship: A Twenty-Year Retrospective' (2012) 24(1) Fordham Environmental Law Review, pp. 87-102, at 101.

62 Green et al., n. 8 above, p. 335.

63 B.C. Karkkainen, 'Collaborative Ecosystem Governance: Scale, Complexity and Dynamism' (2002-03) 21 Virginia Environmental Law Journal, pp. 189-243, at 212-7; Cosens \& Williams, n. 58 above, pp. 1, 10; J. Ebbesson \& C. Folke, 'Matching Scales of Law with Social-Ecological Contexts to Promote Resilience', in Garmestani \& Allen, n. 54 above, pp. 265-92, at 267, 284.

64 C.A. Arnold \& L.H. Gunderson, 'Adaptive Law', in Garmestani \& Allen, n. 54 above, pp. 317-64, at 349 .

65 E.g., Ruhl, n. 51 above, pp. 1382-3.

66 Arnold et al., n. 53 above, p. 9; Cosens et al., n. 54 above, p. 2341.

67 C.A. Arnold \& L.H. Gunderson, 'Adaptive Law and Resilience' (2013) 43(5) Environmental Law Reporter, pp. 10426-43, at 10427; Green et al., n. 8 above, pp. 332-3.

68 Ruhl, n. 51 above, pp. 1379-82.

69 M.H. Benson \& C. Schultz, 'Adaptive Management and Law', in C.R. Allen \& A. Garmestani (eds), Adaptive Management of Social-Ecological Systems (Springer, 2015), pp. 39-59, at 41. 
These features have prompted some to question the capacity of current legal systems to implement resilience approaches. ${ }^{70}$ While there are clear challenges, ${ }^{71}$ there are nonetheless many ways in which the legal system influences resilience. ${ }^{72}$ Legislation may stipulate that the pursuit of resilience is a statutory objective. ${ }^{73}$ Legal processes can also support incremental learning, facilitate more dynamic responses to change, ${ }^{74}$ and provide mechanisms for managing jurisdictional conflicts. ${ }^{75}$ More broadly, the legal system can also articulate and support legal principles and values such as the rule of law, legal certainty, and procedural fairness - which might themselves influence resilience. ${ }^{76}$ For example, affording procedural fairness may broaden the information base from which decision making proceeds. This may result in substantive decision making that better accounts for socio-ecological dynamics, and therefore enhances resilience. ${ }^{77}$ In all these senses, legal systems play an important role in supporting the implementation of resilience approaches to climate change adaptation.

The distributive implications of implementing a resilience approach have received scant attention from legal scholars to date. The role of fair and transparent legal procedures in promoting resilience has been emphasized, but the way in which law shapes the allocation of resources and risks is underexplored. We propose that current approaches to the incorporation of resilience thinking in adaptation law be supplemented with concepts derived from the field of environmental justice. Integrating resilience and environmental justice principles can enhance the value of resilience as both an explanatory and a normative framework. In order to understand how this might work, the next section outlines the principal features of environmental justice and their application to climate adaptation law.

70 E.g., Holling, n. 30 above, p. 1; Garmestani \& Benson, n. 44 above, p. 8; J.B. Ruhl, 'Panarchy and the Law' (2012) 17(3) Ecology and Society online articles, article 31, pp. 2, 4, available at: https:/www.ecologyandsociety.org/vol17/iss3/art31/ES-2012-5109.pdf; B.H. Walker, 'A Commentary on "Resilience and Water Governance: Adaptive Governance in the Columbia River Basin"' (2012) 17(4) Ecology and Society online articles, article 29, p. 1, available at: https://www.ecologyandsociety. org/vol17/iss4/art29/ES-2012-5422.pdf.

71 Ruhl, ibid., p. 2.

72 E.g., Humby, n. 60 above; J. Ebbesson \& E. Hey, 'Introduction: Where in Law is Socio-Ecological Resilience?' (2013) 18(3) Ecology and Society online articles, article 25, p. 1, available at: https://www.ecologyandsociety.org/vol18/iss3/art25/ES-2013-5750.pdf.

73 E.g., Coastal Management Act 2016 (NSW), ss. 3(a), (i) and 6-8.

74 A.S. Garmestani \& C.R. Allen, 'Adaptive Management of Social-Ecological Systems: The Path Forward', in Allen \& Garmestani, n. 69 above, pp. 255-62, at 258-9; Green et al., n. 8 above, p. 332. For explorations of how adaptive management might be facilitated through laws and legal processes, see, e.g., McDonald \& Styles, n. 33 above; C. Slattery, 'Canary in the Coal Mine: Why the Approval Conditions for the Carmichael Mine Reveal the Need to Amend the EPBC Act to Incorporate Adaptive Management Principles' (2016) 33(5) Environmental and Planning Law Journal, pp. 421-42, at 441-2; R.K. Craig et al., 'A Proposal for Amending Administrative Law to Facilitate Adaptive Management' (2017) 12(7) Environmental Research Letters, available at: http://iopscience.iop.org/article/ 10.1088/ 1748-9326/aa7037/meta.

75 Cosens et al., n. 11 above, p. 8; Ebbesson \& Hey, n. 72 above, pp. 1-2; see also text at n. 207 below.

76 J. Ebbesson, 'The Rule of Law in Governance of Complex Socio-Ecological Changes' (2010) 20 Global Environmental Change, pp. 414-22, at 415.

77 Ebbesson \& Hey, n. 72 above, p. 2. The significance of participatory processes is discussed further at nn. 188-195 below. 


\section{ENVIRONMENTAL JUSTICE AND CLIMATE ADAPTATION LAW}

The concept of environmental justice emerged in the US in the late $20^{\text {th }}$ century in response to concern over the location and management of environmental hazards in African American and minority neighbourhoods. ${ }^{78}$ Environmental justice has developed considerably over the three decades since these early analyses of the allocation of environmental hazards. ${ }^{79}$ Contemporary notions of environmental justice are concerned with opportunities to participate in decision making over environmental hazards, and in the development, implementation and enforcement of regulations that affect the substantive fairness of environmental decision making. ${ }^{80}$ Environmental justice scholarship has now expanded beyond the US, ${ }^{81}$ and to transnational and global levels. ${ }^{82}$

In environmental justice scholarship, the 'environment' consists of people's experiences of environmental hazards and benefits, ${ }^{83}$ comprising biophysical and socio-economic conditions that affect people's daily lives. It is this broad approach to the 'environment' that facilitates the application of environmental justice across diverse contexts, including land-use planning, natural resource management, health care, and disaster management. ${ }^{84}$

Contemporary approaches to environmental justice draw on many theoretical and philosophical conceptions of justice, ${ }^{85}$ including distributive and procedural justice, recognition, and the capabilities approach. ${ }^{86}$ Distributive justice requires that substantive inequalities are accounted for in the allocation of both environmental benefits and hazards. ${ }^{87}$ It is concerned primarily with the effects of environmental

78 A. Kaswan, 'Environmental Justice and Environmental Law' (2012-13) 24(2) Fordham Environmental Law Review, pp. 149-79, at 150. This article uses the phrase 'environmental hazards' to include types of environmental harm that already affect communities and the risk of future impacts.

79 R. Bullard, 'Levelling the Playing Field through Environmental Justice' (1998-99) 23(3) Vermont Law Review, pp. 453-78, at 453-4.

80 This statement is heavily influenced by the US Environmental Protection Agency (EPA), 'Environmental Justice', 14 Apr. 2016, available at: https://www.epa.gov/environmentaljustice. See also G. Walker, Environmental Justice: Concepts, Evidence and Politics (Routledge, 2014), pp. 8-11, who notes that environmental justice definitions typically share three common features: (i) a concern with justice 'for people'; (ii) an articulation of the concept of the environment; and (iii) a diverse understanding of justice. Ultimately, however, environmental justice 'def[ies] universal definition'.

81 See Walker, ibid., pp. 23-34; J. Sze \& J.K. London, 'Environmental Justice at the Crossroads' (2008) 2(4) Sociology Compass, pp. 1331-54, at 1341-2; D. Schlosberg, Defining Environmental Justice: Theories, Movements, and Nature (Oxford University Press, 2007), p. 42.

82 Walker, n. 80 above, p. 23; D.N. Pellow, Resisting Global Toxics: Transnational Movements for Environmental Justice (The MIT Press, 2007), p. 5.

83 This emphasis on people's lived experiences distinguishes environmental justice from ecological approaches to justice, although the distinction is probably a matter of emphasis and degree. For an introduction to ecological justice, see B. Baxter, A Theory of Environmental Justice (Routledge, 2005), pp. 7-8. For consideration of non-human aspects of socio-ecological systems through an environmental justice lens, see, e.g., Schlosberg, n. 81 above, pp. 142-57. As for hazards above, the term 'benefit' includes both advantages that are already accruing to a community, and potential future benefits.

84 E.g., Walker, n. 80 above, p. 35.

85 Walker, n. 80 above, pp. 42-53; Schlosberg, n. 81 above, p. 11.

86 In emphasizing these four dimensions, this article draws heavily on Schlosberg's leading contributions to this area of research.

87 R.R. Kuehn, 'A Taxonomy of Environmental Justice' (2000) 30(9) Environmental Law Reporter, pp. 10681-703, at 10684 . 
regulation and processes in practice, irrespective of whether any harm or injustice was intended. ${ }^{88}$ Distribution is typically assessed across geographical (i.e., spatial) and demographic (i.e., socio-economic) dimensions, ${ }^{89}$ and between human and natural systems. However, distributive justice also has an important temporal or intergenerational component, particularly in considering climate change impacts. ${ }^{90}$ Accordingly, a distributive justice approach would encourage attention to the historical allocation of environmental benefits and hazards when assessing the merits of future adaptation strategies.

Procedural justice requires fair decision-making processes $^{91}$ and equal and democratic participation in regulatory activities, rather than substantively fair outcomes. ${ }^{92}$ The procedural dimension is concerned with how decisions are made, who is involved in the administrative processes (as both decision maker and participant), and how participants' views are integrated into decision making. ${ }^{93}$ Procedural justice also has a temporal component, requiring mechanisms for appeal and review of first-instance decision making. ${ }^{94}$

Justice as recognition posits that failure to represent all individuals and communities fairly in decision-making processes is itself a source of inequity. Recognition approaches understand that experiences and evaluations of environmental hazards differ between individuals and communities, and require that different perspectives be acknowledged. 'Misrecognition' can take many forms, ranging from simple ignorance of environmental hazards to deliberate misrepresentation of the impacts of environmental change. ${ }^{95}$ Providing justice by recognition therefore requires consideration of the varied experiences of individuals and communities of environmental hazards and benefits.

The most recent conceptualization of justice is the capabilities approach, which focuses on what individuals and communities require to lead free and fully functioning lives. The capabilities approach cuts across distributive, procedural and recognition dimensions of justice. It emphasizes that inequities in any (or all) of those

88 A. Kaswan, 'Distributive Justice and the Environment' (2002-03) 81(3) North Carolina Law Review, pp. 1031-148, at 1044.

89 Kuehn, n. 87 above, p. 10684.

90 J. Ikeme, 'Equity, Environmental Justice and Sustainability: Incomplete Approaches in Climate Change Politics' (2003) 13(3) Global Environmental Change, pp. 195-206, at 198.

91 This observation includes, but is not limited to, legal processes.

92 Kaswan, n. 88 above, p. 1045.

93 B.J. Preston, 'The Effectiveness of the Law in Providing Access to Environmental Justice', presentation delivered at the 11 th IUCN Academy of Environmental Law Colloquium, Hamilton (New Zealand), 28 June 2013, p. 29, available at: http://www.lec.justice.nsw.gov.au/Documents/preston, \%20brian\% 20-\%20plenary\%20paper\%20environmental\%20justice.pdf.

94 E.g., Kuehn, n. 87 above, p. 10688; A. Kaswan, 'Environmental Justice: Bridging the Gap between Environmental Laws and "Justice" (1997) 47(2) American University Law Review, pp. 221-300, at 236-9.

95 Preston outlines three adverse forms of recognition: (i) non-recognition renders aspects of socioecological systems invisible; (ii) mis-recognition involves inequality of recognition across dimensions of socio-ecological systems; and (iii) mal-recognition involves unfavourable or damaging portrayals of aspects of socio-ecological systems: Preston, n. 93 above, pp. 43-6. For a more detailed outline of justice as recognition, see Schlosberg, n. 81 above, pp. 13-20. 
domains compromise full participation in society. ${ }^{96}$ Developed primarily by Nussbaum and Sen, ${ }^{97}$ the capabilities approach identifies various social, economic, political (including procedural), personal, and environmental attributes essential for human flourishing. ${ }^{98}$ Restricting just one capability compromises full participation in society, and therefore represents an injustice. ${ }^{99}$

These conceptions of justice are interlinked. Synergies are clear in considering barriers to participation in regulatory processes. Barriers to participation raise concerns over procedural justice, while also affecting recognition of justice claims and the capacity of individuals and communities to participate fully in society. The approaches may also conflict. For example, timely administrative procedures may serve the interests of justice by swiftly remedying inequitable distribution of environmental hazards, while also limiting opportunities for participation. The combination of these approaches nonetheless provides a sense of the complexity in developing fair legal responses to environmental risks and hazards.

In recent years, the concept of 'climate justice' has supplemented environmental justice. ${ }^{100}$ Climate justice scholarship often focuses on the allocation of resources on the global scale. ${ }^{101}$ Although concerned largely with mitigation of greenhouse gas emissions, ${ }^{102}$ the literature has more recently expanded to address adaptation funding ${ }^{103}$ and responses to climate-related disasters. ${ }^{104}$ While climate justice is most often associated with the global dimensions of climate policy, it has also been used in assessments of the influence of climate change on the distribution of environmental hazards and benefits at the local level. ${ }^{105}$ In this sense, 'climate justice' applies

96 Schlosberg, n. 81 above, p. 30.

97 E.g., A. Sen, The Idea of Justice (Harvard University Press, 2009), pp. 231-47; and M.C. Nussbaum, Creating Capabilities: The Human Development Approach (Harvard University Press, 2011), pp. 17-20.

98 See R. Lyster, Climate Justice and Disaster Law (Cambridge University Press, 2015), p. 108; Nussbaum, ibid., pp. 33-4. Sen has elected not to provide a 'canonical' list of capabilities: A. Sen, 'Human Rights and Capabilities' (2005) 6(2) Journal of Human Development, pp. 151-66, at 157-60.

99 E.g., Sen, n. 97 above, p. 231.

100 The labels 'environmental' and 'climate' justice are used inconsistently across several contexts: see P. Mohai, D. Pellow \& J. Timmons Roberts, 'Environmental Justice' (2009) 34(1) Annual Review of Environment and Resources, pp. 405-30, at 421.

101 E.g., J. Timmons Roberts \& B.C. Parks, A Climate of Injustice: Global Inequality, North-South Politics, and Climate Policy (The MIT Press, 2006); R. Lyster, 'Adaptation and Climate Justice', in J. Verschuuren (ed.), Research Handbook on Climate Change Adaptation Law (Edward Elgar, 2013), pp. 32-69, at 32; and D. Schlosberg \& L.B. Collins, 'From Environmental to Climate Justice: Climate Change and the Discourse of Environmental Justice' (2014) 5(3) Wiley Interdisciplinary Reviews: Climate Change, pp, 359-74, at 365.

102 E.g., Schlosberg, n. 81 above, p. 46.

103 S. Barrett, 'The Necessity of a Multiscalar Analysis of Climate Justice' (2012) 37(2) Progress in Human Geography, pp. 215-33, at 218.

104 Lyster, n. 98 above.

105 E.g., R.S. Abate, 'Public Nuisance Suits for the Climate Justice Movement: The Right Thing and the Right Time' (2010) 85(2) Washington Law Review, pp. 197-252, at 199-200. In addition, at the domestic level, climate justice is often concerned with 'just transition' to a low carbon society: see, e.g., J.J. Patterson et al., 'Political Feasibility of $1.5^{\circ} \mathrm{C}$ Societal Transformations: The Role of Social Justice' (2018) 31 Current Opinion on Environmental Sustainability, pp. 1-9, at 2; Schlosberg \& Collins, n. 101 above, pp. 370. Just transitions often focus on the importance of ensuring that people are not 'left behind' as society reorganizes in the face of climate change: see, e.g., D.J. Doorey, 'Just Transitions Law: Putting Labour Law to Work on Climate Change' (2017) 30(2) Journal of Environmental Law \& 
environmental justice approaches to climate change harm, focusing on local adaptation efforts. ${ }^{106}$ In our view, climate and environmental justice are best viewed as interrelated fields that are developing in complementary and mutually reinforcing ways. ${ }^{107}$

For the purposes of this article, however, the environmental justice framework offers a more useful lens for analysis of climate adaptation, because it locates climate impacts in their broader environmental context, which includes consideration of non-climatic stressors. ${ }^{108}$ Environmental justice also focuses more directly on peoples' lived experiences of climate impacts at the local level, with less emphasis on theoretical approaches to corrective future allocation of resources on wider scales. ${ }^{109}$ This approach is consistent with the localized nature of adaptation law and governance more broadly. While the availability of resources clearly influences climate adaptation measures and strategies, this article focuses more on the practical implications at local levels, and less on theoretical and philosophical justifications for attributing responsibility to fund adaptation at the global level. ${ }^{110}$

Several scholars in the field of adaption have acknowledged the value of environmental justice approaches. Adger, for example, considers environmental justice a useful lens for analyzing people's experiences of adjusting to climate impacts at the local level. ${ }^{111}$ Paavola and Adger emphasize the importance of procedural justice in connecting local-level adaptation activities with governmental processes. ${ }^{112}$ Most studies recognize the distributive consequences of adaptation, which 'generate[s] a particular incidence of benefits and costs and ... determine[s] the magnitude and distribution of residual climate change impacts'. ${ }^{113}$ For example, physical installations that protect coastal areas from sea level rise and storm surge might increase the economic value and liveability of particular properties, while

Practice, pp. 201-39. On the relationship between climate justice, environmental justice and just transitions, see, e.g., G. Evans \& L. Phelan, 'Transition to a Post-Carbon Society: Linking Environmental Justice and Just Transition Discourses' (2016) 99 Energy Policy, pp. 329-39; R.J. Heffron \& D. McCauley, 'What is the "Just Transition"' (2018) 88 Geoforum, pp. 74-7.

106 Schlosberg \& Collins, n. 101 above, p. 368; see also R.S. Abate, 'Atmospheric Trust Litigation in the United States: Pipe Dream or Pipeline to Justice for Future Generations?’, in R.S. Abate (ed.), Climate Justice: Case Studies in Global and Regional Governance Challenges (Environmental Law Institute, 2016), pp. 543-69, at 546-8.

107 Schlosberg \& Collins, n. 101 above, pp. 370-1; Abate, n. 105 above, pp. 207-8. See also M. Burkett, 'Just Solutions to Climate Change: A Climate Justice Proposal for a Domestic Clean Development Mechanism' (2008) 56(1) Buffalo Law Review, pp. 169-243, at 192-3 (in which climate justice is framed with reference to both national and global scales).

108 Craig, n. 54 above, pp. 43-4.

109 Schlosberg \& Collins, n. 101 above, pp. 368, 370.

110 S. Barrett, 'Local Level Climate Justice? Adaptation Finance and Vulnerability Reduction' (2013) 23(6) Global Environmental Change, pp. 1819-29, at 1819.

111 W.N. Adger, 'Scales of Governance and Environmental Justice for Adaptation and Mitigation of Climate Change' (2001) 13(7) Journal of International Development, pp. 921-31, at 929.

112 J. Paavola \& W.N. Adger, 'Justice and Adaptation to Climate Change', Tyndall Centre Working Paper No. 23, 2002, pp. 1-19, at 15 .

113 Paavola \& Adger, n. 4 above, p. 597. 
potentially concentrating climate impacts on neighbouring (unprotected) areas. ${ }^{114}$ More recent analyses emphasize the importance of recognition forms of justice by incorporating citizens' views in participatory adaptation planning processes, and addressing the structural causes of inequitable and unfair distribution of climate benefits and hazards. ${ }^{115}$ The critical role of environmental justice in understanding and designing adaptation responses underscores the importance of law in achieving these goals.

\subsection{Environmental Justice and Law}

Environmental justice has been applied to laws and legal systems from its inception. Empirical analyses have examined the operation of domestic laws, predominantly in the US ${ }^{116}$ but increasingly also in Australia ${ }^{117}$ and Europe, ${ }^{118}$ with distributive and procedural dimensions of justice typically receiving most attention. ${ }^{119}$ Other contributions have used theoretical developments in environmental justice scholarship to highlight different aspects of the influence of law on environmental justice. ${ }^{120}$ Studies have examined a variety of environmental law contexts, including climate adaptation. ${ }^{121}$

The literature on environmental justice and law treats legal systems in two competing ways. For some, law is seen as a cause of environmental injustice by limiting participation and recognition, ${ }^{122}$ as a significant barrier to addressing the unfair allocation of environmental burdens in a substantial or timely manner, ${ }^{123}$ or as failing to address the distributive consequences of environmental regulation. ${ }^{124}$

114 M.T. Gibbs, 'Why is Coastal Retreat so Hard to Implement? Understanding the Political Risk of Coastal Adaptation Pathways' (2016) 130 Ocean and Coastal Management, pp. 107-14, at 109.

115 D. Schlosberg, L.B. Collins \& S. Niemeyer, 'Adaptation Policy and Community Discourse: Risk, Vulnerability, and Just Transformation' (2017) 26(3) Environmental Politics, pp. 413-37, at 431.

116 Scholarly analyses published in American law journals reflected wider societal interest in environmental justice in the US in the early 1990s: e.g., Bullard, n. 79 above; R.W. Collin, 'Review of the Legal Literature on Environmental Racism, Environmental Equity and Environmental Justice' (1994) 9 Journal of Environmental Law and Litigation, pp. 121-71. The environmental justice framework has since proliferated in analyses of US environmental and natural resources laws: e.g., Kaswan, nn. 78 and 94 above.

117 E.g., Preston, n. 93 above; F. Millner, 'Access to Environmental Justice' (2011) 16(1) Deakin Law Review, pp. 189-207; B. Jessup, 'Justice, Recognition and Environmental Law: The Wielangta Forest Conflict, Tasmania, Australia' (2015) 34(1) University of Tasmania Law Review, pp. 5-33.

118 E.g., M. Stallworthy, 'Sustainability, Coastal Erosion and Climate Change: An Environmental Justice Analysis' (2006) 18(3) Journal of Environmental Law, pp. 357-73; O.W. Pedersen, 'Environmental Justice in the UK: Uncertainty, Ambiguity and the Law' (2011) 31(2) Legal Studies, pp. 279-304.

119 E.g., Millner, n. 117 above, pp. 194-9.

120 E.g., Jessup, n. 117 above, pp. 9-19.

121 E.g., M. Stallworthy, 'Environmental Justice Imperatives for an Era of Climate Change' (2009) 36(1) Journal of Law and Society, pp. 55-74, at 65-9; Millner, n. 117 above, pp. 202-5.

122 E.g., Kaswan, n. 94 above, pp. 268-75; R.J. Lazarus, 'Pursuing Environmental Justice: The Distributional Effects of Environmental Protection' (1992-93) 87(3) Northwestern University Law Review, pp. 787-857, at 825 .

123 On the potential for legal procedures to restrict access to environmental justice, see Kuehn, n. 87 above, pp. 10688-92; E. Gauna, 'The Environmental Justice Misfit: Public Participation and the Paradigm Paradox' (1998) 17(1) Stanford Environmental Law Journal, pp. 3-72, at 16.

124 Kaswan, n. 94 above, pp. 268-70. 
Decision-making procedures rarely provide substantive guidance on how distributive concerns should be addressed ${ }^{125}$ and the main implementation mechanisms of environmental law are not always well suited to addressing distributive concerns. The distributive consequences of environmental or other laws are not systematically monitored, ${ }^{126}$ nor are the cumulative effects of environmental burdens over time, or the interactions that amplify particular impacts. ${ }^{127} \mathrm{~A}$ final critique is that environmental laws rarely address the structural causes of environmental injustice. ${ }^{128}$ Responding to disparate socio-economic and political competences is a substantial challenge and arguably beyond the scope of environmental law, but those laws and processes must at least acknowledge the different experiences of individuals and communities engaging with the legal system.

The contrary view of law and environmental justice sees the legal system as central to procedural justice, ${ }^{129}$ especially because it exposes distributive inequities. ${ }^{130} \mathrm{~A}$ range of mechanisms, including legislative requirements for notice and consultation along with freedom of information legislation, help in ensuring the availability of information relating to the distribution of environmental hazards and benefits. ${ }^{131}$ Review and appeal mechanisms might also be used to delay or prevent actions that would have inequitable distributive effects. ${ }^{132}$ Of course, the availability of legal procedures is no guarantee of their effectiveness in preventing or correcting environmental injustice. Participation may be limited, ${ }^{133}$ while many procedures are 'case' or 'issue' specific and do not automatically lead to systemic change.

The foregoing paragraphs suggest that, despite recognized shortcomings, laws and legal systems can make fundamental contributions to the pursuit of environmental justice, particularly in the context of climate change adaptation. Limiting the adverse effects of laws and legal processes on environmental justice will be essential. Environmentally just adaptation laws must, therefore, address the distributive implications of adaptation by prioritizing the equitable allocation of climate hazards and benefits. ${ }^{134}$ Adaptation laws might, for example, help to enhance the food security of vulnerable populations by shaping domestic and international trade. ${ }^{135}$

\footnotetext{
125 Ibid.; Preston, n. 93 above, pp. 27-8

126 Kaswan, n. 94 above, pp. 268-9.

127 Ibid., p. 242; see also Preston, n. 93 above, pp. 7-8; laws tend to focus on the existence of environmental hazards per se: e.g., Kaswan, n. 78 above, p. 159.

128 See nn. 79, 87-90 above.

129 L. Cole, 'Environmental Justice Litigation: Another Stone in David's Sling' (1994) 21(3) Fordham Urban Law Journal, pp. 523-45, at 527-8.

130 Kaswan, n. 78 above, p. 155; Kaswan, n. 94 above, p. 243.

131 Millner, n. 117 above, pp. 194-6.

132 S.M. Johnson, 'NEPA and SEPAs in the Quest for Environmental Justice' (1997) 30(2) Loyola of Los Angeles Law Review, pp. 565-605, at 578-9; V.P. Mahoney, 'Environmental Justice: From Partial Victories to Complete Solutions' (1999) 21 Cardozo Law Review, pp. 361-414, at 373, 381.

133 Kaswan, n. 94 above, pp. 296-8.

134 On the importance of addressing the distribution of both hazards and benefits, see Lazarus, n. 122 above, pp. 792-6. See also text at nn. 177-187 below.

135 B. Saul, 'Climate Change and Resource Scarcity: Towards an International Law of Distributive Justice', in R. Lyster (ed.), In the Wilds of Climate Law (Australian Academic Press, 2010), pp. 71-94, at 87. On
} 
In addition, adaptation laws must address interacting and cumulative impacts, and expand beyond single 'issues' or 'harms'. ${ }^{136}$ For example, heatwaves and bushfires are often interrelated, and may thus present a " "compound" hazard'; ${ }^{137}$ adaptation laws must account for those scenarios. ${ }^{138}$ Adaptation laws can also enhance environmental justice by building on the legal system's procedural strengths. Supporting the meaningful participation of all individuals and communities must be a priority for adaptation laws, so that the theoretical benefits of legal processes are matched in their practical implementation. ${ }^{139}$ This will require adequate resources and technical support, and greater tolerance of alternative understandings of environmental change. ${ }^{140}$

Climate impacts and the capacities to respond are distributed unevenly. With the emphasis in resilience thinking on dynamism and change, and the focus of environmental justice on fairness in environmental change, there is a compelling case for considering how these two frameworks can be combined to inform climate adaptation law which promotes both resilience and justice. In the next section, we distil guiding principles for blending these theoretical frameworks.

\section{PRINCIPLES FOR PROMOTING RESILIENCE AND JUSTICE THROUGH CLIMATE ADAPTATION LAWS}

Parts 2 and 3 of this article introduced the concepts of resilience thinking and environmental justice, outlined their potential relevance to climate adaptation, and considered their intersections with climate adaptation law. This part elaborates the connections and synergies between the two concepts. It evaluates early literature on the relationship between resilience thinking, environmental justice, and law, and then proposes four principles for their application through laws that promote ijust resilience $^{141}$ in climate change adaptation.

the food security implications of climate change, see T. Wheeler \& J. von Braun, 'Climate Change Impacts on Global Food Security' (2013) 341(6145) Science, pp. 508-13.

136 Mahoney, n. 132 above, p. 410.

137 D. McEvoy, I. Ahmed \& J. Mullett, 'The Impact of the 2009 Heat Wave on Melbourne's Critical Infrastructure' (2012) 17(8) Local Environment, pp. 783-96, at 793.

138 E.g., Emergency Management Victoria, 'State Emergency Response Plan: Extreme Heat Sub-Plan (Edition 2), 2017, pp. 17-8, available at: https://files-em.em.vic.gov.au/public/EMV-web/SERP-Sta teExtremeHeatSub-plan.pdf.

139 J. Mantaay, 'Zoning Law, Health, and Environmental Justice: What's the Connection?' (2002) 30(4) Journal of Law, Medicine and Ethics, pp. 572-93, at 588; see also A. Kennedy, K.A. Schafft \& T.M. Howard, 'Taking Away David's Sling: Environmental Justice and Land-Use Conflict in Extractive Resource Development' (2017) 22(8) Local Environment, pp. 952-68, at 961-3.

140 Gauna, n. 123 above, pp. 14, 66; Kaswan, n. 94 above, pp. 296-8; K. O’Brien, 'Responding to Environmental Change: A New Age for Human Geography?’ (2010) 35(4) Progress in Human Geography, pp. 542-9, at 544 .

141 The term 'just resilience' is used by David Pellow to highlight the importance of drawing together existing scholarship on socio-ecological resilience and environmental justice: D.N. Pellow, 'Critical Environmental Justice Studies’, in B.S. Caniglia, M. Vallée \& B. Frank (eds), Resilience, Environmental Justice and the City (Routledge, 2017), pp. 17-36, at 25-6. Although concurring with Pellow's observations regarding the intersection of socio-ecological resilience and environmental justice, this article adopts a contrasting view of the role of law and the state in the interrelationship of those concepts. 


\subsection{Intersections between Resilience Thinking and Environmental Justice}

Only a handful of scholars have addressed explicitly the intersection of resilience thinking and environmental justice. Caniglia and her co-authors suggest that resilience thinking complements environmental justice. They highlight how different groups experience environmental hazards differently and how inequality shapes experiences of environmental change. ${ }^{142}$ Lyster's account of the development of disaster law similarly hints at a connection between resilience thinking and the capabilities approach to justice, but it does not explore the implications of that connection in detail. ${ }^{143}$ Hansson and Mokeeva develop and apply a joint framework for the assessment of resilience and environmental justice in a coastal community in Indonesia. Their detailed analysis usefully integrates resilience thinking and environmental justice, including through use of the adaptive cycle and panarchy ideas, to explain how an increased emphasis on justice also enhances resilience. ${ }^{144}$

Connections between resilience thinking and environmental justice are implicit in key contributions to resilience thinking and environmental justice scholarship. For example, Schlosberg's more recent work on environmental justice reveals important connections with resilience thinking without directly addressing those principles. $\mathrm{He}$ articulates connections between humans and ecosystems ${ }^{145}$ in terms that mirror the concept of socio-ecological systems; ${ }^{146}$ he explains change processes in a way that reflects the adaptive cycle discussed in Part $2,{ }^{147}$ and also treats events that exacerbate vulnerability like thresholds ${ }^{148}$ that might cause a regime shift when explaining approaches to adaptation. ${ }^{149}$ The capabilities dimension of environmental justice shares some similarities with the adaptability principle of resilience thinking, as it is concerned with the capacity of individuals and communities to respond to changing circumstances. ${ }^{150}$ Schlosberg and Collins also suggest that transformations offer opportunities to address underlying structural causes of environmental injustice. ${ }^{151}$ The multi-scalar nature of environmental problems, central to panarchy theory, also shapes Schlosberg's analysis. ${ }^{152}$ This body of work demonstrates, albeit indirectly, that environmental justice and resilience thinking share important common ground.

\footnotetext{
142 B.S. Caniglia et al., 'Enhancing Environmental Justice Research and Praxis: The Inclusion of Human Security, Resilience and Vulnerabilities Literature' (2014) 8(4) International Journal of Innovation and Sustainable Development, pp. 409-26.

143 Lyster, n. 98 above, pp. 138-9.

144 R. Hansson \& E. Mokeeva, 'Securing Resilience to Climate Change Impacts in Coastal Communities through an Environmental Justice Perspective: A Case Study of Mangunharjo, Semarang, Indonesia' (Master of Science thesis, KTH Royal Institute of Technology, Stockholm (Sweden), 2015), p. 101.

145 See text at nn. 19-21 above.

146 E.g., Schlosberg, n. 81 above, pp. 47-8.

147 See text at nn. 22-34 above.

148 See text at nn. 35-39 above.

149 Schlosberg, n. 81 above, p. 47.

150 N. Doorn, 'Resilience Indicators: Opportunities for Including Distributive Justice Concerns in Disaster Management' (2017) 20(6) Journal of Risk Research, pp. 711-31, at 725.

151 Schlosberg \& Collins, n. 101 above, p. 370.

152 Ibid.
} 
Earlier studies have highlighted the mutually reinforcing dimensions of resilience thinking and environmental justice, and suggested synergies in the principles and frameworks through which the two concepts are operationalized. However, none of these works explore in detail the role of law and legal systems at the intersection of environmental justice and resilience. Caniglia and her co-authors identify governance as a factor relevant to the intersection of resilience and justice without providing further detail. ${ }^{153}$ Hansson and Mokeeva explicitly address governance, and even identify areas for specific potential law reform. ${ }^{154}$ However, their study does not address the structural aspects of legal systems that might impair resilience. It is also confined to the Indonesian domestic setting, and may not readily translate to other legal, social and economic contexts. Far from criticizing these early works, this points to the need for further investigation of the intersection of resilience, environmental justice and legal systems.

\subsection{Guiding Principles for Promoting Justice and Resilience in Climate Adaptation Law}

Drawing on the foregoing examination of resilience thinking, environmental justice, and their interrelationship with law, the discussion below identifies four guiding principles or prescriptions that law must address in order to promote resilience and justice in climate adaptation: (i) the need to prepare for, and respond to, change; (ii) the need to address the distributive effects of climate change and adaptation; (iii) the importance of enhancing participatory processes; and (iv) the need for multiscalar, cross-sectoral legal and governance arrangements. Examples are used throughout to highlight the potential operation of each principle.

\section{Legal arrangements must prepare for, and respond to, change}

Climate adaptation laws can promote resilience and justice by preparing for likely dynamic, non-linear system behaviour. To do so, adaptation laws should include a combination of 'forward-looking' measures that prepare for unexpected developments, and 'back-end' decision-making processes that allow for adjustments in the implementation of laws as circumstances change. ${ }^{155}$ The most commonly cited back-end process is adaptive management, ${ }^{156}$ which recognizes that management prescriptions and regulatory requirements may need to adjust to changes in socioecological systems. ${ }^{157}$ In the Australian context, for example, adaptive management can be facilitated through laws that allow responsive adjustments to environmental

\footnotetext{
153 Caniglia et al., n. 142 above, p. 422.

154 Hansson \& Mokeeva, n. 144 above, pp. 114-5.

155 A.E. Camacho \& R.L. Glicksman, 'Legal Adaptive Capacity: How Program Goals and Processes Shape Federal Land Adaptation to Climate Change' (2016) 87(3) Colorado Law Review, pp. 711-826, at 730-3.

156 Ibid.

157 For an overview of adaptive management, see C.R. Allen \& A. Garmestani, 'Adaptive Management', in Allen \& Garmestani, n. 69 above, pp. 1-10.
} 
licensing or development approval conditions. ${ }^{158}$ Forward-looking laws might be used to develop responses to anticipated future climate impacts, or even to trigger transformations to more desirable system states. For example, planning measures that either prohibit or discourage development in coastal hazard areas will reduce exposure to changing coastal processes. Exposure to inundation and coastal erosion would be reduced in the shorter term, and over the longer term they would promote patterns of settlement where exposure to coastal climate risks is greatly reduced. ${ }^{159}$ Similar planning approaches could also address heightened bushfire risk. The designation and protection of species 'likely to become endangered' and areas of 'future climate habitat' for protected species are examples of laws aimed at anticipating and improving responses to change. ${ }^{160}$

Several legal mechanisms may increase the responsiveness of substantive laws to change in socio-ecological systems. In common law legal systems, some areas of law develop incrementally with each judicial application, and can thus be interpreted and applied in a manner that responds to changing conditions. In determining common law negligence claims, for example, courts may reshape the duty and standard of care reasonably expected of planning authorities in approving developments in areas of increasing flood, bushfire, coastal hazard, or even heatwave risk. ${ }^{161}$ Legislative frameworks can also be designed to respond more readily to change. For example, objects clauses that stipulate climate adaptation as a statutory objective might allow decision makers to adjust existing legal processes to accommodate changing environmental or social conditions. ${ }^{162}$ Broader principles and wider discretion might be preferred to narrower rules and powers, allowing laws to be more readily applied to changing circumstances. ${ }^{163}$ The prescription of minimum 'environmental flow' levels in rivers, as contemplated under Australia's Water Act 2007 (Cth), for example, would enable decision makers to reduce extraction rights and allocations when conditions required. ${ }^{164}$ Internationally, changes to the language of the Convention on Biological Diversity (CBD) to elevate the value of ex situ conservation measures may also provide a stronger foundation for national laws

\footnotetext{
${ }_{158}$ McDonald \& Styles, n. 33 above, pp. 45-9.

${ }^{159}$ For discussion of the difficulties in implementing such an approach, and the complex interactions of law with social, economic and political dynamics, see P. Govind, 'Managing the Relationship between Adaptation and Coastal Land Use Development through the Use of s 149 Certificates' (2011) 7(1) Macquarie Journal of International and Comparative Environmental Law, pp. 94-107.

${ }^{160}$ For a detailed overview of developments under the US Endangered Species Act 1973, see J.M. Chen, 'The Fragile Menagerie: Biodiversity Loss, Climate Change, and the Law' (2018) 93(2) Indiana Law Journal (forthcoming).

${ }^{161} \mathrm{~J}$. McDonald, 'A Risky Climate for Decision-Making: The Liability of Development Authorities for Climate Change Impacts' (2007) 24(6) Environmental and Planning Law Journal, pp. 405-16; P. England, 'Heating Up: Climate Change Law and the Evolving Responsibilities of Local Government' (2008) 13(3) Local Government Law Journal, pp. 209-23, at 216-9.

162 E.g., Biodiversity Conservation Act 2016 (NSW), s. 1.3(d); see P.C. McCormack, 'The Legislative Challenge of Facilitating Climate Change Adaptation for Biodiversity' (2018) 92(7) Australian Law Journal, pp. 546-62.

163 Craig et al., n. 9 above, p. 9.

164 Water Act 2007 (Cth), s. 28; see also B. Docker \& I. Robinson, 'Environmental Water Management in Australia: Experience from the Murray-Darling Basin' (2014) 30(1) International Journal of Water Resources Development, pp. 164-77.
} 
aimed at anticipating and responding to changed climatic conditions. ${ }^{165}$ Finally, climate adaptation laws might even be drafted so that their substantive content adjusts automatically to changing circumstances. ${ }^{166}$ In the US, for example, rolling easements place restrictions on use of land automatically upon the occurrence of natural events, such as the recession of shoreline vegetation in coastal areas. ${ }^{167}$

While flexibility is essential for the implementation of adaptive responses to climate impacts, ${ }^{168}$ enabling flexibility in climate adaptation laws creates risks from a justice perspective. Accelerating the speed or frequency at which decisions are made may reduce opportunities for public participation and judicial review. ${ }^{169}$ Reducing the capacity for citizens to observe and contribute to decision-making processes diminishes transparency, accountability, and potentially legitimacy. ${ }^{170}$ High levels of discretion may also be open to manipulation and the influence of interest groups. ${ }^{171}$ Care is therefore required to safeguard core values, such as procedural fairness, public participation, and the rule of law.

An important procedural mechanism to ensure that responses to change do not come to the detriment of environmental justice is the routine collection and evaluation of information about environmental and other conditions. This requires dramatic improvements in the scope and rigour of current monitoring activities. Other improvements that can support a learning approach to legal decision making ${ }^{172}$ include requirements for routine reporting on a standard suite of climate impact indicators, with requirements that decision makers demonstrate how they have taken such data into account. ${ }^{173}$

Finally, climate adaptation laws must themselves be monitored for their responsiveness to change. ${ }^{174}$ Statutory provisions commonly referred to as sunset clauses, which place a time limit on the operation of laws or require review of the operation and effect of the law, should be used to stimulate law reform through legislative, agency, and democratic processes. ${ }^{175}$ Mandating a five-year review of adaptation plans, for example, may help to ensure that legal requirements reflect

165 Rio de Janeiro (Brazil), 5 June 1992, in force 29 Dec. 1993, Art. 9, available at: http://www.cbd.int/ convention/text.

166 J. Pidot, 'Governance and Uncertainty' (2015-16) 37(1) Cardozo Law Review, pp. 113-84, at 164-72.

167 McDonald \& Styles, n. 33 above, pp. 48-9; J.G. Titus, 'Rolling Easements', Climate Ready Estuaries and US EPA, June 2011, available at: http://risingsea.net/easement.

168 Ruhl, n. 13 above, p. 418.

169 McDonald \& Styles, n. 33 above, p. 53; Craig et al., n. 74 above, pp. 8-10.

170 Cosens et al., n. 54 above, pp. 2350-1.

171 Biber \& Eagle, n. 9 above, pp. 790, 828-31.

172 A. Camacho, 'Adapting Governance to Climate Change: Managing Uncertainty through a Learning Infrastructure' (2009-10) 59(1) Emory Law Journal, pp. 1-77, at 65-70.

173 E.g., Climate Change Act 2017 (Vic), s. 36(c).

${ }^{174}$ Flatt, n. 32 above, p. 290; see also J.B. Wiener \& D.L. Ribeiro, 'Environmental Regulation Going Retro: Learning Foresight from Hindsight' (2016) 32(1) Journal of Land Use and Environmental Law, pp. $1-73$.

175 J. McDonald, 'A Short History of Climate Adaptation Law in Australia' (2014) 4(1-2) Climate Law, pp. 150-67, at 157; see also D. De Caro et al., 'Legal and Institutional Foundations of Adaptive Environmental Governance' (2017) 22(1) Ecology and Society online articles, article 32, pp. 5, 9, 13, available at: https://www.ecologyandsociety.org/vol22/iss1/art32/ES-2016-9036.pdf. 
scientific advances, changing socio-economic conditions and contemporary community expectations. Alternatively, laws might stipulate deadlines by which objectives, targets and measures should be reviewed following release of major international climate science outputs, such as assessment reports of the Intergovernmental Panel on Climate Change (IPCC). ${ }^{176}$

Developing climate adaptation laws that better prepare for, and respond to, change will facilitate both resilience and justice. Laws attuned to the inherent dynamics of socio-ecological systems should enhance resilience by facilitating more timely responses to climate hazards. They may also promote justice by better recognizing different experiences of climate hazards. In turn, this will enable substantive inequities to be addressed more promptly. Laws attuned to change may also respond more effectively to the loss of key capabilities, such as access to core ecosystem services like water. Of course, resilience and justice require that law does more than merely identify changes; substantive responses to the distributive implications of climate adaptation are also required. These are considered below.

\section{Laws must address the distributive effects of climate change and adaptation}

Adaptation to climate change will create winners and losers. ${ }^{177}$ The individuals and communities likely to bear the brunt of climate impacts often have the most limited capacity to respond to them. For example, as many parts of the world become drier, communities with insecure access to water will experience further disadvantage, while people or entities holding legal entitlements to water and having the resources necessary to protect and utilize such entitlements may benefit from those impacts. ${ }^{178}$ This highlights that, to promote resilient and just adaptation, laws must address the distributive effects of both climate change impacts and adaptation measures. Climate adaptation laws that are blind to these dynamics are likely to entrench inequity.

There are at least three ways in which climate adaptation laws and processes can address distributive issues. Firstly, decision-making processes should explicitly consider the inequitable distribution of climate hazards and benefits. ${ }^{179}$ Revealing those inequities requires attention to existing social and political structures, including the conferral of risks and benefits in the operation of climate adaptation laws themselves. For example, lower income communities are often concentrated in areas exposed to

176 E.g., Climate Change Response Act 2002 (New Zealand), s. 225.

177 J.B. Ruhl, 'The Political Economy of Climate Change Winners' (2012-13) 97(1) Minnesota Law Review, pp. 206-77, at 222. The question of how 'wins' and 'losses' associated with climate impacts are determined and valued raises complex considerations: see K. O'Brien et al., 'Toward a Sustainable and Resilient Future', in C.B. Field et al. (eds), Managing the Risks of Extreme Events and Disasters to Advance Climate Change Adaptation: A Special Report of Working Groups I and II of the Intergovernmental Panel on Climate Change (Cambridge University Press, 2015), pp. 437-86, at 456-7.

178 A.S. Kiem, 'Drought and Water Policy in Australia: Challenges for the Future Illustrated by the Issues Associated with Water Trading and Climate Change Adaptation in the Murray-Darling Basin' (2013) 23 Global Environmental Change, pp. 1615-26, at 1624.

179 R.J. Lazarus, 'The Meaning and Promotion of Environmental Justice' (1994) 5 Maryland Journal of Contemporary Legal Issues, pp. 1-12, at 7. 
heatwave. ${ }^{180}$ Once this phenomenon is acknowledged in decision making, planning and building laws should ensure that development and building design are suited to temperature extremes and, where possible, actually mitigate the urban heat island effect. Those distributive measures may help to reduce the individual burden of heatwaves (by reducing energy consumption for cooling, for example), thus enhancing the capacity of those communities to adapt to other changes (such as impacts on health and wellbeing). The effectiveness of laws that explicitly recognize and account for inequitable distributions of impacts and adaptive capacity should be regularly evaluated. Evaluation processes should be broadly participatory and include safeguards that ensure that the perspectives of the intended beneficiaries of such efforts are understood.

Another key mechanism by which laws can address the distributive impacts of climate change is to require articulation of how competing interests are to be prioritized in decision making. ${ }^{181}$ This includes priorities about resource allocation or trade-offs between the protection of natural against built infrastructure assets (for example, wetlands $v$. coastal infrastructure), between different uses of resources (such as irrigation $v$. domestic water consumption), as well as between different places or groups within the same community. When determining operational responses to fire, for example, emergency management laws might specify that resources be focused first on protecting human lives, then on critical public infrastructure, private property, and environmental assets (in that order). Setting out priorities in advance improves transparency and promotes public participation in actually establishing those distributive objectives. More inclusive and transparent decision-making processes may also help in resolving tensions between competing interests. ${ }^{182}$ Distributive priorities that are clearly articulated can also be more easily reviewed in light of changing circumstances. $^{183}$

For laws to promote just adaptation in the long term, they must also account for the structural causes of environmental injustice. It is obviously beyond the scope of sectoral laws such as land-use planning or emergency management legislation to address all the underlying causes of poverty or social disadvantage. At the very least, however, adaptation laws should acknowledge, and where possible address, imbalances in power relations that affect how legal processes operate in practice, including mechanisms for participation. ${ }^{184}$ Providing access to relevant experts, ${ }^{185}$

180 J. Byrne et al., 'Could Urban Greening Mitigate Suburban Thermal Inequity? The Role of Residents' Dispositions and Household Practices' (2016) 11(9) Environmental Research Letters 095104, pp. 1-16, at 1-2, available at: http://202020vision.com.au/media/72662/could_urban_greening_ mitigate_suburban_thermal_inequity.pdf.

181 E.g., Emergency Management Victoria, Victorian Bushfire Handbook (State of Victoria, 2015), p. 1, available at: http://files.em.vic.gov.au/Doctrine/ManHand/VIC-BushfireHandbook.pdf.

182 This article does not take a stance on the relative merits of these priorities; it merely provides a simple illustrative example. Note, too, that the competing interests outlined for the purposes of this example may not be mutually exclusive in all circumstances. However, further exploration of these nuances is beyond the scope of this article.

183 See text at nn. 155-176 above.

184 A. Kaswan, 'Domestic Climate Change Adaptation and Equity' (2012) 42(12) Environmental Law Reporter, pp. 11125-43, at 11139, 11141.

185 Kaswan, n. 94 above, pp. 296-8. 
while also ensuring that information relating to climate impacts is presented to citizens in an appropriate manner and form, will empower communities to utilize legal processes and remedies. The delivery of adaptation strategies through mechanisms that entrench unfair distributive outcomes should also be avoided. While market mechanisms will play an important role in adaptation, reliance on unregulated markets carries the risk that economically powerful vested interests prosper at the expense of weaker groups. ${ }^{186}$ For example, insurance premiums are likely to increase in areas of existing vulnerability (such as those increasingly exposed to fire, cyclone or flood risk), and requirements to rebuild to higher standards will increase the costs of recovery for uninsured groups, thus exacerbating vulnerability to climate impacts. Without careful regulation, such mechanisms may perpetuate structural injustices, reducing both resilience and justice. ${ }^{187}$

Adaptation laws that address inequities in the allocation and experiences of climate impacts clearly address the core concern of environmental justice that hazards and benefits are distributed equitably. Yet, addressing these concerns also promotes resilience. Ensuring that climate impacts are not funnelled inequitably towards vulnerable communities will preserve adaptive capacity in the face of unavoidable climate impacts. Where appropriate, transformative change might also be triggered (changes in planning and building laws to address heatwave, for example) in order to avoid or minimize inequities in experiences of climate impacts. Understanding people's lived experiences of climate change impacts and addressing distributive issues requires wider public participation. The development of participatory processes that better account for power imbalances is addressed in the following principle.

\section{Laws must promote participation in adaptation processes}

Climate adaptation laws can enhance resilience and justice by prescribing fair and inclusive processes. The size of the adaptation imperative, the resources involved, and the potential for special interest influence in the allocation of adaptation benefits underscore the importance of accountability and transparency. ${ }^{188}$ Public participation should, in general, ${ }^{189}$ be extended to all stages of legal processes, including the design, development, implementation and enforcement of adaptation measures. Traditional checks on decision-making power, such as merits or judicial review, should remain key accountability mechanisms. ${ }^{190}$ Freedom of information laws and the range of public consultation processes common to environmental and natural resources law provide some measure of openness. However, there are

\footnotetext{
186 Kaswan, n. 184 above, p. 11139.

187 McDonald, n. 10 above, p. 286; see also A. Kaswan, 'Energy, Governance and Market Mechanisms' (2018) 72(2) University of Miami Law Review, pp. 476-579, at 482-4.

188 Cosens et al., n. 54 above, pp. 2350-1.

189 Time constraints (the operationalization of policies in response to extreme weather events, for example) may militate against public consultation. The weight afforded inputs from participatory processes may also vary, as noted in the following paragraph.

190 Milner, n. 117 above, pp. 196-7.
} 
opportunities to build on the existing procedural strengths of law by increasing the breadth and importance of public participation. ${ }^{191}$

Broader participation is effectively meaningless unless contributions might actually influence the design and implementation of climate adaptation measures. Participatory processes in adaptation law and decision making must move beyond tokenism to recognize some degree of citizen power. ${ }^{192}$ Revealing the ways in which public contributions influence decisions - through steps as simple as indicating where draft or proposed laws are amended after public comment - will help to demonstrate the influence of participatory processes and thus further empower citizens. However, laws cannot, and perhaps should not, guarantee that all contributions will be reflected in adaptation strategies - especially where expert knowledge relating to climate impacts is vital for decision making or where resources are limited. The operationalization of emergency management policies in response to fire or flooding events, for example, provides little room for public participation.

Innovative mechanisms such as citizens' juries or consensus conferencing - in which a representative sample of citizens is brought together to hear from experts and propose recommendations to address socially and politically challenging issues - could be trialled as a more cost-effective way of fulfilling obligations of participation in important policy choices. ${ }^{193}$ Increased participation will also expand the sources of knowledge and data upon which adaptation decisions are based. Citizen-science initiatives such as the Redmap website, ${ }^{194}$ which enables recreational fishers and divers to log and record sightings of marine species beyond their historical range, afford valuable mechanisms for engaging affected communities and enhancing the information base on which adaptation decisions are made. ${ }^{195}$

Participation is a clear concern for both environmental justice and resilience. Wider participation can increase adaptive capacity because drawing on a wider range of knowledge and data opens the way for novel adaptation strategies and measures. Similarly, a wider information base may provide earlier signals of changes in key variables, which in turn allow for adaptive behaviour that avoids undesirable transformations or facilitates desirable shifts. To best understand system dynamics, however, adaptation laws must also recognize cross-scalar interactions. This is addressed in the fourth principle below.

\footnotetext{
191 Cosens et al., n. 11 above, pp. 6-7.

192 S.R. Arnstein, 'A Ladder of Citizen Participation' (1969) 35(4) American Institute of Planning Journal, pp. 216-24, at 217.

193 C.D. Myers, T. Ritter \& A. Rockway, 'Community Deliberation to Build Local Capacity for Climate Change Adaptation: The Rural Climate Dialogues Program', in W.L. Filho \& J. Keenan (eds), Climate Change Adaptation in North America: Fostering Resilience and the Regional Capacity to Adapt (Springer, 2017), pp. 9-26, at 13-4; see also O. Woolley, Ecological Governance: Reappraising Law's Role in Protecting Ecosystem Functionality (Cambridge University Press, 2014), pp. 210-4.

194 Available at: http://www.redmap.org.au.

195 Mahoney, n. 132 above, p. 411.
} 


\section{Laws must operate across sectors and scales}

Climate impacts span multiple sectors, occur on geographic scales from the local to the global, and across timescales. Effective adaptation to climate impacts therefore requires the development of laws that also span multiple sectors and spatial and temporal scales, ${ }^{196}$ preferably creating a network of protection that interacts to build diversity and redundancy. ${ }^{197}$ Diversity encourages the use of multiple adaptation strategies, which, in combination, increase the overall likelihood that adaptation objectives are achieved. ${ }^{198}$ Building diversity also creates redundancy, so that the limitations (or failure) of one method might be counteracted by others - a legal safety net if one sector, scale or governance actor fails to perform its functions. ${ }^{199}$ Biodiversity conservation laws, for example, might pursue a range of adaptation strategies, including increasing the scope of protected areas, actively managing sites or species, and ex situ conservation or translocation of species threatened by climatic shifts. ${ }^{200}$ Laws may implement each of these strategies through diverse methods. For example, expansion of the protected area network may occur through a combination of public acquisitions, covenanting of private land, and other incentives. ${ }^{201}$ If managed effectively, laws that facilitate greater diversity and redundancy increase the likelihood of just and resilient adaptation, but they must make provision for resolving conflicts between the priorities of different sectors and scales. To be sure, laws that facilitate diversity and redundancy may be problematic; laws might promote adaptation strategies or methods of implementation that are in tension, for example, where translocating species threatens the conservation values of protected areas. Laws themselves may conflict. ${ }^{202}$ Although overlapping adaptation strategies and laws may compromise efficiency and increase uncertainty for decision makers in the short term, they may help to avoid optimization or regime shifts within socioecological systems over longer time spans. ${ }^{203}$

Climate adaptation laws can also play a vital role in coordinating adaptation measures across sectors, modes, and scales. ${ }^{204}$ Adaptation to climatic change will require a wide range of responses to address various impacts. Although some

${ }^{196}$ J. Peel, L. Godden \& R.J. Keenan, 'Climate Change Law in an Era of Multi-Level Governance' (2012)

1(2) Transnational Environmental Law, pp. 245-80, at 272-5.

197 Cosens et al., n. 11 above, pp. 2, 4.

198 K. Kotschy et al., 'Principle 1: Maintain Diversity and Redundancy', in R. Biggs, M. Schlüter \& M.L. Schoon (eds), Principles for Building Resilience: Sustaining Ecosystem Services in SocialEcological Systems (Cambridge University Press, 2015), pp. 50-79, at 53-4.

199 Ibid., pp. 52-3.

200 P. McCormack \& J. McDonald, 'Adaptation Strategies for Biodiversity Conservation: Has Australian Law Got What It Takes?' (2014) 31(2) Environmental and Planning Law Journal, pp. 114-36.

201 Ibid.; McDonald, McCormack \& Foerster, n. 53 above.

202 For example, in a federal system, local, regional and national laws may impose overlapping, and perhaps contradictory legal requirements: see, e.g., A.D. Tarlock, 'Biodiversity Federalism' (1995) 54 Maryland Law Review, pp. 1315-53; C. McGrath, 'One Stop Shop for Environmental Approvals a Messy Backward Step for Australia' (2014) 31(3) Environmental and Planning Law Journal, pp. 164-91, at 166.

203 As discussed in Part 2 above.

204 Craig, n. 54 above, pp. 60-1. 
measures may be complementary, others are likely to conflict. Limiting land clearing to facilitate biodiversity conservation, for example, may unintentionally increase bushfire risk. ${ }^{205}$ Contrarily, fire management laws that oblige property owners to maintain a large firebreak around buildings may undermine nature vegetation laws. ${ }^{206}$ Climate adaptation laws can help to minimize and manage these conflicts by improving mechanisms for information sharing. ${ }^{207}$ This could include requirements for government agencies to publish information or consult with other stakeholders when developing adaptation measures. More ambitiously, laws could support learning across sectors and scales by requiring agencies to monitor and report publicly on the effectiveness of adaptation efforts. A good example of this is the sharing of adaptation plans and evaluations of their implementation under the United Nations Framework Convention on Climate Change (UNFCCC), ${ }^{208}$ via its Secretariat. $^{209}$

Climate adaptation laws can establish substantive coordination of adaptation measures. Bridging organizations - institutions that span legal or sectoral boundaries - can draw governments and/or agencies together to coordinate or integrate adaptation efforts. This approach may be especially useful where socioecological and jurisdictional boundaries are misaligned. River systems such as the Murray-Darling river system in Australia, which spans four states and countless local municipalities, ${ }^{210}$ or the Rio Grande River in North America, which spans not just multiple US states, but Mexico as well, ${ }^{211}$ provide a useful illustration. Developing legal arrangements that enhance cooperation and coordination across subnational, national and international boundaries is therefore likely to enhance adaptation measures. $^{212}$ Through these three approaches, climate adaptation laws can facilitate the development of coherent and more effective management of responses to climate impacts.

205 D.A. Driscoll et al., 'Resolving Conflicts in Fire Management using Decision Theory: Asset-Protection versus Biodiversity Conservation' (2010) 3(4) Conservation Letters, pp. 215-23, at 216-7, 221; D.K. Bardsley et al., 'Climate Change, Bushfire Risk, and Environmental Values: Examining a Potential Risk Perception Threshold in Peri-Urban South Australia' (2018) 31(4) Society and Natural Resources, pp. 424-41, at 427.

206 A. Foerster, A. Macintosh \& J. McDonald, 'Transferable Lessons for Climate Change Adaptation Planning? Managing Bushfire and Coastal Climate Hazards in Australia' (2013) 30(6) Environmental and Planning Law Journal, pp. 469-90, at 474.

207 Flatt, n. 32 above, p. 284; Camacho, n. 172 above, pp. 65-70.

208 New York, NY (US), 9 May 1992, in force 21 Mar. 1994, available at: https:/unfccc.int/resource/docs/ convkp/conveng.pdf.

209 UNFCCC Secretariat, Decision 1/CP.16, 'The Cancún Agreements: Outcome of the Work of the Ad Hoc Working Group on Long-Term Cooperative Action under the Convention' (15 Mar. 2011), UN Doc. FCCC/CP/2010/7/Add.1., para 20. See also UNFCCC, 'Overview of UNFCCC Knowledge Resources on Adaptation', available at: http://www4.unfccc.int/sites/nwp/Pages/UNFCCC-knowledgeresources.aspx.

${ }^{210}$ For an overview and history of governmental arrangements in the Murray-Darling Basin, see D. Connell, 'The Murray-Darling Basin', in D.E. Garrick et al. (eds), Federal Rivers: Managing Water in Multi-Layered Political Systems (Edward Elgar, 2014), pp. 309-22.

${ }^{211}$ M.H. Benson et al., 'Water Governance Challenges in New Mexico's Middle Rio Grande Valley: A Resilience Assessment' (2014-15) 51(1) Idaho Law Review, pp. 195-228, at 200-5.

212 Garmestani \& Benson, n. 44 above, p. 7; Cosens et al., n. 54 above, pp. 2346, 2352. 
Cross-sectoral and multi-scalar processes have the potential to promote both resilience and justice. Although cross-sectoral and multi-scalar legal arrangements address most directly the panarchy concept of resilience thinking, ${ }^{213}$ interventions across various geographic areas, sectors and time scales may be required to distribute the costs and benefits of climate adaptation fairly. ${ }^{214}$ Addressing changes in coastal processes, for example, may require highly localized emergency responses to flooding events, supported by longer-term adjustments in land-use planning and insurance practices. ${ }^{215}$ Procedural and recognition approaches to justice may also be enhanced by the availability of multiple processes and means of redress. Logically, crosssectoral and multi-scalar legal arrangements will offer more opportunities for participation. Those legal arrangements may promote justice as recognition by providing more - and more varied - opportunities for input into decision-making processes. For example, local-level processes may involve community meetings and events, while higher-level governmental processes may require participation through formal written submissions. Increasing the array of participatory processes may require additional resources, ${ }^{216}$ and the hypothetical benefits of enhanced participation may not be achieved in reality. ${ }^{217}$ Nevertheless, cross-sectoral and multi-scalar processes have, at least in theory, the capacity to enhance both resilience and justice in climate adaptation.

The four principles are clearly interlinked, and the nature of these relationships requires further consideration. In some instances, the principles seem to be mutually reinforcing. For example, approaches that prepare for and respond nimbly to change are likely to consume fewer resources, so savings can be redistributed to address other priorities. In other instances, the principles may conflict. Broader and more inclusive participatory processes, for example, may be resource- and time-intensive, which undermines rapid responsiveness to change. ${ }^{218}$ The trade-offs required to reconcile tensions, and to maximize co-benefits of the principles, may well be context- and scale-dependent. Consideration of these trade-offs between these principles is an important focus of future research.

Together, the four principles emphasize considerations which are central to the development and implementation of climate adaptation laws that promote resilience thinking and environmental justice. Some essential considerations (effective feedbacks, for example) cut across the four principles outlined above, and are therefore addressed independently. The principles are necessarily broad, and their implementation would be likely to require further tailoring on a 'case-by-case' basis.

213 See text at nn. 40-44 above.

214 E.g., W.N. Adger, N.W. Arnell \& E.L. Tompkins, 'Successful Adaptation to Climate Change Across Scales' (2005) 15(2) Global Environmental Change, pp. 77-86.

215 J. McDonald, 'The Ebb and Flow of Coastal Adaptation in Australia', in R. Abate (ed.), Climate Change Impacts on Ocean and Coastal Law: US and International Perspectives (Oxford University Press, 2015), pp. 627-47, at 631-43.

216 See text at nn. 139-140 above.

217 R. Few, K. Brown \& E.L. Tompkins, 'Public Participation and Climate Change Adaptation: Avoiding the Illusion of Inclusion' (2007) 7(1) Climate Policy, pp. 46-59.

218 See text at n. 140 above. 
For example, climate adaptation laws focused on longer-term impacts that develop incrementally may prioritize different aspects of the principles when compared with laws that address more abrupt disturbances. Nevertheless, the principles provide a starting point for further investigation and analysis of the operation of existing laws and processes, which might be implemented (at least in part) through incremental reform and development of existing laws and processes.

\section{CONCLUSION}

This article has argued that climate adaptation laws can be designed and implemented to promote both socio-ecological resilience and environmental justice. It suggests four guiding principles to achieve this objective. Legal arrangements must (i) prepare for, and respond to, change; (ii) address the distributive effects of climate change and adaptation; (iii) promote participation in adaptation processes; and (iv) cross sectors and scales. These principles build on existing literature by integrating key elements of resilience thinking and environmental justice. In combination, they provide a framework for the development of climate adaptation laws.

The four principles proposed in this article are not exhaustive, and are intended to prompt further discussion. There are substantial opportunities for further research that evaluates the operation of existing laws with reference to these prescriptions. Systematic empirical testing of the principles, particularly through applied case studies that consider a range of different jurisdictions, scales, and climate impacts, is clearly required. In turn, it is likely that the four principles will require further refinement in light of more detailed empirical analysis. Comparative analyses may usefully highlight strengths and weaknesses of approaches employed in various jurisdictions. $^{219}$ To the extent that adaptation laws are necessarily localized and context-specific, the challenges of transferring and upscaling adaptation laws and processes that promote resilience and justice will also require further analysis.

Moreover, the way in which principles are given effect through law will be important. Some measures, such as information sharing and meaningful participation, might require little by way of formal law reform. Decision makers and executive agencies might develop informal working groups or networks, or go beyond prescribed minimum levels of public engagement, in order to promote resilience and justice within the scope of existing laws and processes. Courts and agencies may also promote resilience and justice in applying existing laws to new circumstances. However, other aspects of the principles are likely to require more substantive reform. For example, amending statutory frameworks to incorporate new legislative objectives or sunset clauses will require time, and might present political challenges. Iterative implementation of these more substantial reforms might also be advantageous. For example, it may be wise to trial a sunset clause and review process in one statute before implementing extensive changes to legislative drafting practices.

219 E.g., X. He, 'Legal and Policy Pathways of Climate Change Adaptation: Comparative Analysis of the Adaptation Practices in the United States, Australia and China' (2018) 7(2) Transnational Environmental Law, pp. 347-73. 
This step-by-step approach would facilitate testing and refinement of approaches and strategies for achieving meaningful law reform over time.

The need to develop climate adaptation laws that simultaneously facilitate the pursuit of resilience and justice is clear. Climate impacts are already affecting individuals and communities on local, regional and national scales, and this will only increase in frequency and severity. Existing legal frameworks are not well suited to the implementation of innovative adaptation policies based on resilience thinking, and fail to adequately address the disproportionate allocation of climate risks borne by the most vulnerable members of society, or vulnerable ecosystems. Laws and reforms that address these shortcomings must be developed and implemented without delay, so that the law can best fulfil its crucial role in facilitating resilient and just adaptation to climatic change. 